\title{
CHINA'S MALLEABLE SOVEREIGNTY ALONG THE BELT AND ROAD INITIATIVE: THE CASE OF THE 99-YEAR CHINESE LEASE OF HAMBANTOTA PORT
}

\author{
Maria Adele Carrai*
}

I. Introduction . . . . . . . . . . . . . . . . . . . . . . . 1062

II. Hambantota Port: A Strategic 'Pearl' along the Maritime Silk Road ................... 1067

III. Hambantota Concession Agreement and the Legacies of Colonialism . . . . . . . . . . . . . . . . 1075 of Намваnтота . . ....................... 1086

V. Conclusion .......................... 1097

Since China Merchant Port Holdings and Sri Lanka signed a 99-year Concession Agreement for the 15,000 acres of Hambantota Port in Sri Lanka in 2017 as part of the Belt and Road Initiative (BRI), media outlets and academics have used the agreement as a proof of China's new interventionist and expansionist attitude, realized through debt-trap diplomacy. China has a reputation as the stronghold of Westphalia sovereignty. However, the BRI and increased Chinese investments abroad may modify its attitude toward sovereignty. In protecting its interests and its nationals abroad, is China adopting similar legal regimes and techniques to those adopted by Western powers in the nineteenth and twentieth centuriesor is China taking a different path? This article, using local media reports and interviews of important stakeholders, looks at the available sections of the Concession Agreement of Hambantota Port and contextualizes the agreement in light of international law and evolving Chinese conceptions of sovereignty. It argues that China, relying on the contested and political notion of sovereignty, is using similar legal techniques as Western powers used since the nineteenth century, and that its understanding of sovereignty continues to be malleable in order to accommodate new evolving interests.

* Maria Adele Carrai is a recipient of a three-year Marie Curie Fellowship at KU Leuven ([PEGASUS $]^{2}$ Marie Sklodowska-Curie Fellowships No 665501) and an Adjunct Associate Research Scholar at the Weatherhead East Asian Institute of Columbia University. Dr. Carrai has published in various peer-reviewed journals. Her first book, Sovereignty in China. A Genealogy of a Concept since 1840 (CUP, 2019) provides a historical perspective through which to better understand the path China is taking as a normative actor within the international order. She would like to thank Prof. Jerome A. Cohen, Aaron Halegua, Prof. Luigi Nuzzo, Prof. Federica Violi and Tonchev Plamen for their helpful comments and support in writing this article. 
Specifically, with the unfolding of the BRI and Chinese investments abroad, China increasingly must protect its investments, property, and people outside of its sovereign borders. Although there are only a handful of cases of China encroaching upon the sovereignty of other countries, and Sri Lanka sovereignty in Hambantota is a legal fact, China, relying on the ambivalence of the international law that regulates international leases could compromise the principles of sovereign equality and non-interference.

\section{INTRODUCTION}

Sovereignty has been a framing concept for international society since the emergence of modern international law in the eighteenth and nineteenth centuries. It is linked with the idea of territoriality, and is understood as a state's strategy of control by the state of a specific geographical area, over which the state exercises a series of exclusive sovereign rights. Sovereignty continues to structure international society and the work of the United Nations is:

[B] ased on the principle of the sovereign equality of all its Members. ... All Members shall refrain in their international relations from the threat or use of force against the territorial integrity or political independence of any state, or in any other manner inconsistent with the Purposes of the United Nations. ${ }^{1}$

When international law and sovereignty were translated into Chinese over the course of the nineteenth century, Qing intellectuals and diplomats gradually appropriated them and used them to oppose the foreign encroachment upon Chinese territory often realized through international lease agreements. Hong Kong was the first territory to be leased in perpetuity to Great Britain after the First Opium War in 1842, and it was returned to China only in 1997 after more than "a century of humiliations," characterized by what China has defined as unjust concessions and unequal treaties that placed the Qing empire (1644-1911) and later Republican China (1912-1948) in a degrading position. ${ }^{2}$ Since the Second

1. U.N. Charter art. 2, III $1,4$.

2. See David Scott, China and the International System, 1840-1949: Power, Presence, and Perceptions in a Century of Humiliation xi-xiii, 1322 (SUNY Press 2008) (The book describes the emergence of the Chinese rhetoric of the 'Century of Humiliations' starting from the First and Second Opium Wars, respectively of 1840-1842 and 1857-1860) . 
Opium War (1856-60), China has become one of the world's strongest supporters of the principles of sovereignty and nonintervention in the affairs of other countries. ${ }^{3}$ After the establishment of the People's Republic of China (PRC), these principles became the foundation of its foreign policy, as defined by the five principles of peaceful coexistence included in the Constitution. ${ }^{4}$ Although the PRC under Mao Zedong's rule actively attempted to export socialism, supporting domestic politics in guerrilla movements in Mozambique, Nigeria and Angola,${ }^{5}$ China has been cautious about authorizing sanctions and military interventions, ${ }^{6}$ and has opposed such actions in the Security Council and beyond. ${ }^{7}$ Chinese jurists have often labeled humanitarian intervention as a Western imperialistic strategy designed to interfere with and exert undue influence in domestic affairs. ${ }^{8}$ In Chinese academic and political debates, human rights derive only from the national sovereign, such that no other country has the right to interfere for the sake of protecting the human rights in foreign territories. ${ }^{9}$ China has consistently opposed unilateral intervention, and instead has supported UN peacekeeping operations since 1981,

3. See Maria Adele Carrai, Sovereignty in China: A Genealogy of a Concept Since 1840, 152-181, 220-227 (forthcoming July 2019).

4. XIANFA pmbl (1982) (China).

5. Colin Legum, The Soviet Union, China and the West in Southern Africa, 54 Foreign Affairs 4 (1976).

6. Carrai, supra note $3,165$.

7. Allen Carlson, Helping to Keep the Peace (Albeit Reluctantly): China's Recent Stance on Sovereignty and Multilateral Intervention, 77 PAC. AFF. 1, 11 (2004); Christopher Holland, Chinese Attitudes to International Law: China, the Security Council, Sovereignty, and Intervention, N.Y.U. J. OF INT'L L. \& Pol.: ONLINE FORUM (July 17, 2012), https:/ / nyujilp.org/chinese-attitudes-to-international-law-china-the-security-council-sovereignty-and-intervention.

8. Carlson, supra note 7 , at 13.

9. See, e.g., Zhou Qi (周琪), Meiguo Renquan Waijiao Zhengce (美国人权外交政策) [US Human Rights Policy], in Dangdai GuOJI ZZhengzhi CONGSHU (当代国际政治丛书) [CONTEMPORARY InTERnational Politics Books] (Shanghai: Shanghai Renmin Chubanshe 2001); ZhaO LujIE (赵鲁杰), He Renxue (何仁学) \& Chen Fangwu (沈方吾), Meiguo QuanQIU BAQUAN Yu ZhongGuo Mingyun (美国全球覇权与中国命运) [US GLOBAL HEgemony and the fate of China] (Beijing: Beijing Chubanshe, 1999) Wen Lijuan (温丽娟), GuOWai Diguo ZhuYi Lun YANJiU (国外帝国主义论研究) [Thesis of Guilin University]; Wei Min (魏敏), Renquan de Guoji Baohu Yu Bu Ganshe Neizheng 人权的国际保护与不干涉内政 [The protection of human rights and the principle of non-interference], 5 ReNMIN RiBaO人民日报, Apr. 16, 1991. 
recently becoming its second largest financial contributor. ${ }^{10}$ The PRC is also recognized as attaching less conditionalities to its financing than Western powers and the Bretton Woods Institutions, which instead make their loans conditional on transforming governance and political systems and respecting human rights in the recipient countries. ${ }^{11}$

China's non-interventionist position on sovereignty has been restated in policy documents related to the Belt and Road Initiative (BRI), which President Xi Jinping announced in 2013. The State Council's National Development and Reform Commission (NDRC) reports that

on the basis of respecting each other's sovereignty and security concerns, countries along the Belt and Road should improve the connectivity of their infrastructure construction plans and technical standard systems, jointly push forward the construction of international trunk passageways, and form an infrastructure network connecting all sub-regions in Asia, and between Asia, Europe and Africa step by step. ${ }^{12}$

The initiative "upholds the Five Principles of Peaceful Coexistence: mutual respect for each other's sovereignty and territorial integrity, mutual non-aggression, mutual non-interference

10. Samuel S. Kim, China, the United Nations and World Order 53-54 (2015). According to Obert Hodzi, China is now intervening in other countries through the UN. This would be in the case of South Sudan, where China has strong economic interests and has lobbied the UN to authorize peacekeeping operations that also protect Chinese investments, property, and people. Obert Hodzi, The End of China's Non-Intervention Policy in Africa, Critical Studies of the Asia-Pacific, 1-7 (Mark Beeson ed., 2019); see United Nations Peacekeeping, China, https://peacekeeping.un.org/en/china.

11. See Diego Hernandez, Are "New" Donors Challenging World Bank Conditionality? (Aiddata, Working Paper No. 12, 2016) (The article describes the World Bank approach to conditionality and investigates how the new presence of loans from China is reducing the conditionality of the World Bank); Christopher Kilby, The Political Economy of Conditionality: An Empirical Analysis of World Bank Loan Disbursements, 89 J. OF Dev. Econ. 51 (2009) (The article offers a detailed empirical analysis on the way the World Bank has used conditionality).

12. Press Release, National Development and Reform Commission, Ministry of Foreign Affairs, and Ministry of Commerce of the People's Republic of China, Vision and Actions on Jointly Building Silk Road Economic Belt and 21st-Century Maritime Silk Road (Mar. 28, 2015), http:// en.ndrc.gov.cn/newsrelease/201503/t20150330_669367.html. 
in each other's internal affairs, equality and mutual benefit, and peaceful coexistence." 13 It further stresses that China respects "the paths and modes of development chosen by different countries," and seeks the "biggest common denominator." 14 However, the 99-year Concession Agreement for the 15,000 acres of Hambantota Port signed in 2017 as part of the BRI between the Sri Lankan government and China Merchant Port Holdings (CMPort), a Chinese state-owned enterprise (SOE), might embody a new modus operandi that encroaches upon the sovereignty of countries where China invests. ${ }^{15}$ Importantly, the Hambantota lease is part of a broader trend of China expanding its reach well beyond its sovereign borders, which has been often the norm for great powers. For example, in 2017 the People's Liberation Army signed a ten-year lease agreement at U.S. \$20 million per year for a 36-hectare Djibouti facility to establish a naval base for its anti-piracy operations. ${ }^{16}$ At the same time, China has also become increasingly assertive of its own sovereign claims, exemplified in the building of artificial islands in the South China Sea against the claims of its neighbors, and the abduction of booksellers and journalists in Hong Kong and Thailand. ${ }^{17}$

Due to its "Going Out" strategy—a strategy designed to encourage its enterprises to invest overseas that was launched in 1999 and which culminated in the BRI-China's non-in-

13. Id.

14. Id.

15. Ankit Panda, Sri Lanka Formally Hands Over Hambantota Port to Chinese Firms on 99-Year Lease, The Diplomat (Dec. 11, 2017), https://thediplomat. com/2017/12/sri-lanka-formally-hands-over-hambantota-port-to-chinesefirms-on-99-year-lease/; Ana Pararajasingham, Sri Lanka: Sovereignty Compromised, The Diplomat (Sept. 9, 2017), https://thediplomat.com/2017/09/ sri-lanka-sovereignty-compromised/; Kiran Stacey, China Signs 99-Year Lease on Sri Lanka's Hambantota Port, Fin. Times (Dec. 11, 2017), https:// www.ft.com/content/e150ef0c-de37-11e7-a8a4-0a1e63a52f9c.

16. Michael Kovrig, With an Influx of Blue Helmets and Cash, China's Role in African Security Grows More Pervasive, China Files (Oct. 23, 2018), http:// www.chinafile.com/reporting-opinion/viewpoint/influx-of-blue-helmetsand-cash-chinas-role-african-security-grows-more; Nicole Hirt, Djibouti, in 13 Africa Yearbook Vol. 13, 294, 298 (2017).

17. Barbara Demick, Why Did China Kidnap Its Provocateurs?, New YoRkeR (Feb. 16, 2016), https://www.newyorker.com/news/news-desk/why-didchina-kidnap-its-provocateurs; Alex W. Palmer, The Case of Hong Kong's Missing Booksellers N.Y. Times (Apr. 3, 2018), https://www.nytimes.com/2018/ 04/03/magazine/the-case-of-hong-kongs-missing-booksellers.html. 
terventionist stance on sovereignty could be changing, and debates in China are ongoing about how to balance sovereignty against the increasing need to protect Chinese investments and people abroad. Li Ming of Peking University, for example, has argued that sufficient flexibility should be reserved in the application of the principle of non-intervention in the BRI context. ${ }^{18}$ Various official documents have also started to discuss this changing position, acknowledging that while sovereignty and non-intervention are essential, China has new interests abroad that have to be protected. ${ }^{19}$ Scholar Samuli Seppänen has suggested that because the objective of the BRI is to open up foreign countries to Chinese investments, and to protect those investments, sovereignty could take a different form and might promote a "developmental interventionism" in order to minimize the many political, cultural, and legal risks associated with the project. ${ }^{20}$ Many other scholars have also discussed the transformation of China's policy and its shift toward an increasing interventionist stance abroad. ${ }^{21}$

In the light of the current debates about evolving Chinese conceptions of sovereignty, this article looks at the lease of Hambantota Port in the broader context of the international law surrounding land leases. This article examines how China will protect its investments abroad as it constructs infrastructure in the countries along the BRI, whether it will change its stance on sovereignty and non-intervention, and whether

18. Li Ming (李鸣), Guoji Fa Yu “Yidai Yilu” yanjiu (国际法与 “一带一 路”研究) [International law and 'one belt, one road'], 1 FAxuE ZAZH (法学杂志) 11 (2016).

19. See, e.g., Chu Yin (储殷), Zhongguo Waijiao de Bian Yu Bu Bian-Lun Haiwai Liyi Baohu Yu “Bu Ganshe Neizheng” Yuanze (中国外交的变与不变一 一论海外利益保护与“不干涉内政”原则) [China's Diplomacy is changing or not - On the Protection of Overseas Interests and the Principle of "Do Not Intervene in Internal Affairs"], PeOple's Daily Online (人民网) (Sept. 23, 2014), http:// theory.people.com.cn/n/2014/0923/c83850-25715394.html (Chu Yin argues that due to China new interests abroad and investments in foreign countries, its long-time support for an absolute principle of non-interference might also be revised).

20. Samuli Seppänen, Performative Uses of Sovereignty in the Belt and Road Initiative, in International Governance and the Rule of Law in China under the One Belt One Road Initiative 32, 47-48 (Zhao Yun ed., 2018).

21. See Hodzi, supra note 10 (Obert Hozdi provides examples in African countries in which China is changing its attitude about non-interference, and shows that there are instances in which China was more prone to intervene to protect its interests abroad). 
China is using similar legal regimes and techniques to those adopted by Western powers to project their imperial power in the nineteenth and twentieth centuries and encroach upon other countries' sovereignty, including the Qing empire. By looking at the Hambantota case, this article aims to shed light on the current Chinese attitude toward sovereignty. First, it introduces the strategic importance of Sri Lanka and the Hambantota Port for the Chinese Maritime Silk Road, the sea route part of the BRI. This article describes how both the policies of Sri Lankan President Mahinda Rajapaksa's government (2005-2015) and the miscalculations of Chinese state-owned enterprises (SOEs) contributed to Sri Lanka's debt crisis, leading the new government which came into power in 2015 to sign the 99-year Hambantota Port lease agreement. Second, the article looks at this Concession Agreement in the context of the international law governing lease agreements, and colonial history. Third, it explores some of the legal intricacies the agreement will raise in relation to Sri Lanka's sovereignty. In conclusion, the article discusses some aspects related to evolving Chinese conceptions of sovereignty, arguing that China, relying on the ambivalence of the international law that regulates international leases, seems to be following a consolidated legal path set forth by Western colonial powers in the nineteenth and twentieth centuries that ultimately reveals the malleable and political nature of sovereignty and international law itself.

\section{Hambantota Port: A Strategic 'Pearl' along the Maritime Silk RoAd}

The BRI is a Chinese geo-economic and developmental strategy aimed at improving connectivity through investments in infrastructure in Central Asia. According to Wang Jisi, one of the scholars who contributed to devising the initiative, for China the BRI constitutes "a new international geostrategic pillar for its Western Development strategy." ${ }^{22}$ Serving multiple economic, diplomatic, and military purposes, the BRI was launched in 2013 incorporating pre-existing projects. Although the Digital Silk Road-which will help shape the fu-

22. Wang Jisi, Marching Westwards: The Rebalancing of China's Geostrategy, in The World in 2020 According to China: Chinese Foreign Policy Elites Discuss Emerging Trends in International Politics 129, 129 (2014). 
ture of the global Internet—and the Polar Silk Road-aimed at facilitating connectivity and sustainable economic and social development in the Arctic-have now become part of the BRI, BRI's original name, Yidaiyilu一带一路 initially referred only to its two main components: the Economic Belt, which focuses on infrastructure development across Central Asia, and the Maritime Road, a development strategy designed to boost infrastructure connectivity throughout Southeast Asia, Oceania, the Indian Ocean, and East Africa. Under the BRI, China has already participated in the construction and operation of a total of 42 ports in 34 countries. ${ }^{23}$ These investments in port infrastructure and navy capabilities have continued to raise concern that these efforts are not only economic in nature, but also military, as part of China's efforts to become a maritime power. In particular, literature on the subject has used the notion of "a string of pearls" to refer to the ongoing development of the port projects in Gwadar (Pakistan), Chittagong (Bangladesh), Marao Atoll (Maldives), Sittwe and Khaukphyu (Myanmar), and now Hambantota (Sri Lanka) as a Chinese attempt to encircle the Indian Ocean and India. ${ }^{24}$

Sri Lanka and Hambantota play a strategic role for the Maritime Silk Road in the Indo-Pacific region, and in the past decade Sri Lanka has received substantial investments, loans, and aid from China. ${ }^{25}$ Sri Lanka is located in the Indian Ocean on the world's busiest shipping lane and the world's second busiest oil transit chokepoint. ${ }^{26}$ China's interest in this

23. Janne Suokas, China Invests in 42 Overseas Ports under Belt and Road Project, Global Times (Jul. 27, 2018), https://gbtimes.com/china-invests-in42-overseas-ports-under-belt-and-road-project.

24. See, e.g., Gurpreet S. Khurana, China's 'String of Pearls' in the Indian Ocean and Its Security Implications, 32 Strategic Analysis 1 (2008); Christopher J. Pehrson, String of Pearls: Meeting the Challenge of China's Rising Power across the Asian Littoral (Strategic Stud. Inst., U.S. Army War College 2006) (describing China's rising influence through ports and airfields from the South China Sea through the Strait of Malacca, across the Indian Ocean, and on to the Arabian Gulf known as the "String of Pearls").

25. Zhao Yan (赵妍), Han Ban Tuo Ta Gang-Haisi Shizilu Kou de Weilai Xinxing (汉班托塔港一一海丝十字路口的未来新星) [Hambantota Port the Future New Star of the Crossroads of the Maritime Silk Road], ZHONGYANG Guangdian Zong Tai Guoji Zaixian (中央广电总台国际在线) (Aug. 31, 2018), http://news.cri.cn/zaker/20180831/7db28ede-2d71-5975-420b923928129273.html.

26. U.S. Energy Info. Admin., World Oil Transit Chokepoints, https:// www.eia.gov/beta/international/regions-topics.php?RegionTopicID=WOTC 
shipping lane is huge: not only does it import two-thirds of its oil through this corridor, but it also relies on it to export its products to Europe and Africa. According to the president of Shanghai Institute of International Studies (SIIS), Professor Chen Dongxiao, "Sri Lanka enjoys strategic and unique geographic location within South Asia as well as in the Maritime Silk Route. This pivotal position enables Sri Lanka to play a very important role in Belt and Road Initiative, hence greater Sri Lanka-China economic cooperation is relevant." 27 Chinese long-term economic and strategic goals have coincided with the Sri Lanka government preferences. ${ }^{28}$ The two countries thus enjoy a long-standing good relationship that both can used as leverage against India, and elsewhere. In the past decade, Sri Lanka has offered Chinese banks an opportunity to profit from the high interest rates Sri Lanka accepted on loans for major infrastructure building. For Sri Lanka, especially under Rajapaksa's government, China represented one of the few countries willing to provide aid and financing without major strings attached to often un-profitable infrastructure projects, such as the empty airport of Mattala Rajapaksa International Airport. ${ }^{29}$

(last updated Jul. 25, 2017) (Data show that along the Strait of Malacca transit 26 million barrels of oil per day, second only to the Strait of Hormuz, where transit 19 million barrels of oil per day); Dhruva Jaishankar, Indian Ocean Region: A Pivot for India's Growth, Brookings (Sept. 12, 2016), https://www.brookings.edu/opinions/indian-ocean-region-a-pivot-for-indias-growth/ (Discusses the strategic importance of the Indian Ocean).

27. Nisthar Cassim, Key Role for Sri Lanka in China's Belt and Road Initiative, Daily Fin. Times (July 20, 2017), http://www.ft.lk/special-report/key-rolefor-sri-lanka-in-chinas-belt-and-road-initiative-shanghai-institute-of-internati onal-studie/22-629539. Addressing issues relating to sustainable development and the Maritime Silk Road Initiative was the theme of the September 2017 roundtable conference organized by the China-Sri Lanka Cooperation Studies Centre (CSLCSC) of the Pathfinder Foundation in Colombo. See Round Table Discussion on Maritime Silk Road E Sustainable Development, PATHFINDER FOUNDATION (Sept. 2, 2017), http://pathfinderfoundation.org/ track2partners/2015-07-16-17-22-35/2015-07-16-17-24-56/286-round-tablediscussion-on-maritime-silk-road-a-sustainable-development-september-2017.

28. Neil DeVotta, China's Influence in Sri Lanka, in Rising China's Influence in Developing Asia 129, 134 (Evelyn Goh ed., 2016).

29. See Wade Shepard, The Story Behind the World's Emptiest International Airport, Forbes (May 28, 2016), https://www.forbes.com/sites/wadeshep ard $/ 2016 / 05 / 28 /$ the-story-behind-the-worlds-emptiest-international-airportsri-lankas-mattala-rajapaksa/\#4f203e987cea (The author described some of the non-profitable Chinese investments in Sri Lanka, including Mattala 
China is currently Sri Lanka's largest foreign investor. Chinese investment has accounted for $35 \%$ of foreign direct investments (FDI) into Sri Lanka up to September 2017, with its FDI for 2017 expected to total U.S. $\$ 1.36$ billion. ${ }^{30}$ It has also lent over U.S. $\$ 6$ billion to previous governments for infrastructure projects, but, as will be further discussed below, its increased investments during the Rajapaksa government had more to do with Sri Lankan government decisions and corruption rather than Chinese policies directly aimed at creating debt traps. The development of Hambantota Port is one of the China-financed BRI projects that has attracted the most attention. ${ }^{31}$ The port is located on Sri Lanka's southern tip in the Hambantota district, which has a total of population of 206,588 and is within 10 nautical miles of the world's busiest maritime lane, through which approximately 200 to 300 ships sail daily. ${ }^{32}$ A comprehensive deep-water port of 17 meters, the

Rajapaksa International Airport, the empty airport that costed \$209 million, $\$ 190$ of which coming in the form of loans from China).

30. China Tops in Sri Lanka's FDI for 2017, XinHUA (Dec. 19, 2017), http:/ /www.xinhuanet.com/english/2017-12/09/c_136813922.htm.

31. Other projects during the Rajapaksa period financed by the Chinese government included: the Colombo Port City Project, which was to be built by the China Communications Construction Company (CCCC) by reclaiming an artificial island of about 575 acres from the sea, with the largest single foreign direct investment of U.S. $\$ 1.5$ billion (it was suspended by the new government in 2016, but relaunched under a new name in 2017); the Mahinda Rajapaksa National Tele Cinema Park, for 2 billion Sri Lanka Rupies; the Mahinda Rajapaksa International Cricket Stadium, for 700 million Sri Lanka Rupees; the Norochcholai Power Plant, for U.S. $\$ 1.35$ billion; the Southern Expressway, for 776 billion Sri Lankan Rupees; and the Mattala Rajapaksa International Airport, for 26 billion Sri Lankan Rupees. See DeVotta, supra note 28 at 145-147 (The authors details the various Chinese investments in Sri Lanka); Maria Abi-Habib, How China Got Sri Lanka to Cough Up a Port, N.Y. Times, (June 25, 2018), https://www.nytimes.com/ 2018/06/25/world/asia/china-sri-lanka-port.html (Looks at the Chinese loans financing infrastructure projects in Sri Lanka); Sudha Ramachandran, China Expands Its Footprint in Sri Lanka, The Diplomat (Sept. 11, 2018), https://thediplomat.com/2018/09/china-expands-its-footprint-in-sri-lanka/ (Describes the various projects financed by China in Sri Lanka).

32. Shalini Mariyathas, Nihal Perera, \& Mohamed Yehiya, What Development Has Done to a Town: Lessons from Hambantota, Sri Lanka, 5 BHúmI, The Planning Res. J. 1 (2016); Zhao Ruidong (赵瑞东) et al., 斯里兰卡汉班托塔港二期码头结构优化 - [Optimization for Wharf Structure

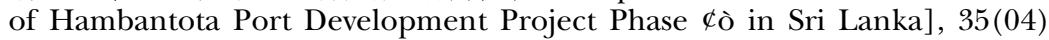
中国港湾建设 [China Harbour EngineERING] 24-27 (2015). 
Hambantota Port is capable of handling mega vessels and currently has 10 berths and a quay length of up to 3,487 meters. ${ }^{33}$ Its berths are specialized for containers, bulk cargos, general cargos, RO-RO cargos, and liquid bulk. ${ }^{34}$ Hambantota Port has been important for the Sri Lankan economy since ancient times-first known to be operational around 250BC, and used by Arabian and Chinese merchants-but had never been developed and lags behind the main Port of Colombo.

If properly developed, Hambantota Port could have great potential for future expansion to serve as a maritime hub and transshipment center in a region stretching from South Asia to East Africa. Despite the negative results of some feasibility studies, ${ }^{35}$ the idea of developing the port became a reality when Rajapaksa identified Hambantota, his ancestral home district, as a pillar of his "Mahinda Chinthana Idiri Dekma" (Mahinda Rajapaksa: Vision for the Future), launched in 2010 during his sixth presidential election campaign. ${ }^{36}$ This signaled a larger plan to make Sri Lanka a logistical hub between Singapore and Dubai, transforming the country's south, which was devastated from the 2004 tsunami, into an economic engine. ${ }^{37}$ At the time, Sri Lanka made an open request for funding, specifically approaching India and the United States, but due to the potential investment risks, no other country beside China offered loans for the Hambantota Port. ${ }^{38}$ China agreed to finance the project through three phases. The first began in 2008 and became operational in 2010, with an estimated investment of U.S. \$361 million, ultimately totaling \$508 mil-

33. CMPort Acquire stakes of Hambantota Project, SAFETy4SEA (July 25, 2017), http://www.cmport.com.hk/enTouch/news/Detail.aspx?id=10007328.

34. Id.

35. Feasibility Study for a New Major Seaport in Sri Lanka, Ramboll Group, https://ramboll.com/projects/group/hambantotaport (last visited Feb. 8, 2019).

36. For an elaboration of this idea, see Department of National Planning \& Ministry of Finance and Planning, Sri Lanka, The Emerging WonDer of Asia: Mahinda Chintana-Vision for the Future (2010), https:// www.adb.org/sites/default/files/linked-documents/cps-sri-2012-2016-oth01.pdf (The paper articulates Mahinda's vision of development, in which infrastructure development played a key role) .

37. Id. at 4-7.

38. See DeVotta, supra note 28. 
lion. ${ }^{39}$ China's Export Import (EXIM) Bank funded $85 \%$ of the first phase at a relatively high interest rate of $6.3 \%$, and the Sri Lanka Ports Authority (SLPA) funded the additional $15 \%{ }^{40}$ This first phase included the construction of the basic port and other facilities for shipbuilding, bunkering, ship repairing, and crew changing. ${ }^{41}$ The second phase commenced in November 2012 and has largely been completed. It cost an estimated U.S. $\$ 810$ million, and involved the construction of several berths, including the main, multipurpose, transition, and oil berths; a feeder container terminal; an artificial island; a cofferdam; and other yards, handling facilities, and access roads. ${ }^{42}$ Further, the port's entrance channel was deepened from $-16 \mathrm{~m}$ to $-17 \mathrm{~m} .{ }^{43}$ The Rajapaksa government was not able to see the third phase unfold, as he was defeated in the 2015 elections.

The Rajapaksa government spent around U.S. \$6 billion on roads, ports, and railways after the civil war ended in May 2009, and most of the financing, in the form of loans and aid, has come from China and India. ${ }^{44}$ Sri Lanka pays an interest rate ranging from 2.9 to $8.25 \%$ for the various loans from China. ${ }^{45}$ According to the 2017 Annual Report of the Central Bank of Sri Lanka, the country's total external debt was U.S. \$51.824 billion, among which outstanding Chinese loans accounted for only $10.6 \%$, or U.S. $\$ 5.5$ billion. ${ }^{46}$ According to Sri Lanka’s Finance Ministry Annual Report 2017, market bor-

39. Leasing of Hambantota Port: Rationale, Economic Benefits and Way Forward, Daily Fin. Times (Jan. 27, 2017), http://www.ft.lk/article/593997/ Leasing-of-Hambantota-Port:-Rationale-economic-benefits-and-way-for ward.

40. Anjelina Patrick, China - Sri Lanka Strategic Hambantota Port, NAT'L Mar. Found. (Apr. 13, 2017), http://www.maritimeindia.org/View\%20Pro file/636276610966827339.pdf.

41. Leasing of Hambantota Port, supra note 39.

42. Id:; Patrick, supra note 40.

43. Sri Lanka Port Authority, Port of Hambantota (2016), https:// www.flandersinvestmentandtrade.com/export/sites/trade/files/trade_pro posals/Port $\% 20$ of $\% 20$ Hambantota $\% 20$ RFP.pdf.

44. DeVotta, supra note 28, at 148.

45. DeVotta, supra note 28, at 149.

46. Sri Lanka Ministry of Finance, Annual Report 176 (2017), http:// www.treasury.gov.lk/documents/10181/12870/2017.pdf/2bce4f3d-ebde4409-b2b5-c8a0801b3edc 
rowings accounted for $39 \%$ of the country's external debt. ${ }^{47}$ Loans from the Asian Development Bank (ADB) accounted for $14 \%$, loans from Japan accounted for $12 \%$, loans from the World Bank accounted for $11 \%$, and loans from India accounted for 3\%. ${ }^{48}$ As Sri Lankan debt accumulated, Rajapaksa lost the 2015 presidential election to Maithripala Sirisena, who gained support in opposition to the Rajapaksa's government corruption and its non-transparent deals with China, considered conducive to a form of servitude for Sri Lanka. ${ }^{49}$ While the new government wanted to preserve good relations with China, it also promised to reassess Rajapaksa's poorly considered China-funded projects. ${ }^{50}$ By 2015 , however, some $95 \%$ of Sri Lanka's government revenue was going toward servicing its debt, and the government initiated debt renegotiations with China. ${ }^{51}$ China requested a dominant equity share in Hambantota Port in return for writing off the debt. ${ }^{52}$

After various negotiations, on July 29, 2017, the Ministry of Ports and Shipping, the SLPA, and CMPort signed the initial Concession Agreement in relation to Hambantota Port. ${ }^{53}$ The agreement set up two separate joint-venture companies to oversee the port's commercial and security operations: the Hambantota International Port Group (HIPG) and Hambantota International Port Services Company (HIPS) .54 These are de facto auxiliaries of CMPort, which retains an $85 \%$ share of HIPG with SLPA holding the remaining $15 \% .55$

47. Shen Shiwei, Underwater Myth of Sri Lanka's Hambantota Port Deal Comments, Daily Fin. Times (Aug. 10, 2018), http://www.ft.lk/opinion/Under water-myth-of-Sri-Lanka-s-Hambantota-Port-deal/14-660586.

48. Central Bank of Sri Lanka, Annual Report 171 (2017), https:// www.cbsl.gov.lk/en/publications/economic-and-financial-reports/annualreports/annual-report-2017; Shen, supra note 47.

49. Profile: Mahinda Rajapaksa, BBC News (Aug. 18, 2015), https:// www.bbc.com/news/world-asia-24918281.

50. Darren J. Lim \& Rohan Mukherjee, What Money Can't Buy: The Security Externalities of Chinese Economic Statecraft in Post-War Sri Lanka, Asian SEcurity 1, 2, 9 (Dec. 28, 2017).

51. Yogita Limaye, Sri Lanka: A Country Trapped in Debt, BBC News (May 26, 2017), https://www.bbc.com/news/business-40044113.

52. Abi-Habib, supra note 31.

53. Skandha Gunasekara, Last-Minute Amendments to H'tota Concession Agreement, SRi Lanka Fin. Times (Dec. 7, 2017), http://www.ft.lk/front-page/ Last-minute-amendments-to-H-tota-Concession-Agreement/44-644709.

54. Id.

55. Id. 
CMPort retains a $58 \%$ share of HIPS, with SLPA holding $42 \% .{ }^{56}$ The SLPA is thus a de facto minority shareholder in both companies. ${ }^{57}$ According to the agreement, CMPort will lease the Hambantota Port for 99 years and invest up to U.S. $\$ 1,120$ million in the port, as well as other marine-related activities in connection to the port, for a total area of 15,000 acres of land. 58

The agreement is not available to the public, but CMPort has published some extracts of it online: Potential Disposable Transaction Concession Agreement in Relation to Hambantota Port, released on July 25, 2017 and its updated version, disclosed on December 8, 2017.59 The analysis below is based on these documents and the material available online through various Sri Lanka local journals, international journals, Sri Lankan officials' speeches, and interviews with officials and academics. The Hambantota Port project was immediately labeled a BRI success story in the Chinese media. ${ }^{60}$ In Sri Lanka, however, the 99-year lease has been harshly criticized as equivalent to selling Sri Lankan sovereignty. ${ }^{61}$ The agreement has also spurred alarm in media and academic journals elsewhere about Chinese debt-trap diplomacy, well summarized by Constantino Xavier, then fellow at the U.S.-

56. $I d$.

57. Everything To Know About The Hambantota Port Lease, LANKa News PAPERs (Aug. 9, 2017), https://www.lankanewspapers.com/2017/08/09/every thing-to-know-about-the-hambantota-port-lease/.

58. Abi-Habib, supra note 31; Ranga Sirilal, Chinese Firm Pays $\$ 584$ Million in Sri Lanka Port Debt-to-Equity Deal, Reuters, June 20, 2018, https:// www.reuters.com/article/us-sri-lanka-china-ports/chinese-firm-pays-584-mil lion-in-sri-lanka-port-debt-to-equity-deal-idUSKBN1JG2Z6.

59. Press Release, China Merchants Port Holdings Company Limited, Potential Disclosable Transaction Concession Agreement in Relation to Hambantota Port, Sri Lanka (Jul. 25, 2017), http://www.cmport.com.hk/ UpFiles/bpic/2017-07/20170725061311456.pdf.

60. Id.

61. Ankit Panda, Sri Lanka Formally Hands Over Hambantota Port to Chinese Firms on 99-Year Lease, The Diplomat (Dec. 11, 2017), https://thediplomat. com/2017/12/sri-lanka-formally-hands-over-hambantota-port-to-chinesefirms-on-99-year-lease/; Ana Pararajasingham, Sri Lanka: Sovereignty Compromised, The Diplomat (Sept. 9, 2017), https://thediplomat.com/2017/09/ sri-lanka-sovereignty-compromised/; Kiran Stacey, China Signs 99-Year Lease on Sri Lanka's Hambantota Port, Fin. Times (Dec. 11, 2017), https:// www.ft.com/content/e150ef0c-de37-11e7-a8a4-0a1e63a52f9c. 
based Carnegie Endowment for Peace, who remarked that the lease

is part of a larger modus operandi by China in the region ... . Beijing typically finds a local partner, makes that local partner accept investment plans that are detrimental to their country in the long term, and then uses the debts to either acquire the project altogether or to acquire political leverage in that country. ${ }^{62}$

According to media and academic reports, Chinese debt-trap diplomacy has seriously hampered Sri Lankan sovereignty and should be heeded as a warning about Chinese attitudes toward international law and its increased power in shaping geopolitics and international norms. ${ }^{63}$ However, as it will be further discussed below, the situation is more complex that how it is often portrayed by media, and there are deficiencies in the very international law that should regulate international leases and protect sovereignty.

\section{Hambantota Concession Agreement and the Legacies of Colonialism}

For those familiar with Chinese history, the 99-year lease of the 15,000 acres of Hambantota Port immediately evokes the colonial history of China, particularly the leases and concessions that encroached upon Chinese territorial and jurisdic-

62. K. T. Ganeshalingam, China's Larger Geopolitical Strategy of the Hambantota Port Project of Sri Lanka, 6 Int'L Multidisciplinary Res. J. 2., 42-51 (2016).

63. See, e.g., Abi-Habib, supra note 31; Brahma Chellaney, Sri Lanka the Latest Victim of China's Debt-Trap Diplomacy, SRI LANKa Brief (Dec. 26, 2017), http://srilankabrief.org/2017/12/sri-lanka-the-latest-victim-of-chinas-debttrap-diplomacy (Argues for China adopting a debt trap diplomacy and Sri Lanka is the clearest example); Jonathan E. Hillman, Game of Loans: How China Bought Hambantota, Ctr. For Strategic and Int'l Stud. (Apr. 2, 2018), https://www.csis.org/analysis/game-loans-how-china-boughthambantota (Looks at how China played a game of loans to trap Sri Lanka into a debt); Harsh V. Pant, China's Debt Trap Diplomacy, Commentary, ОвSERver Res. Found. (Aug. 3, 2017), https://www.orfonline.org/research/ chinas-debt-trap-diplomacy (Describes China's Debt Trap Diplomacy); Umesh Moramudali, Sri Lanka's Debt and China's Money, The Diplomat (Aug. 16, 2017), https://thediplomat.com/2017/08/sri-lankas-debt-and-chinasmoney (Makes the argument that China is gaining through forcing Sri Lanka into debt). 
tional sovereignty, fueling the narrative of its century of humiliations. In the nineteenth and twentieth centuries, Western powers used lease agreements to secure infrastructure development in foreign territories, demarcate colonial boundaries in Africa, and secure military bases on foreign territories. ${ }^{64}$ Since the collapse of the Soviet Union, Russia has used lease agreements to secure military bases in new sovereign nations that emerged from the Union, while the United States has created a "leasehold empire" based on overseas military bases. ${ }^{65}$ During the last century of the Qing empire, leases were used by Western powers to open up the Chinese market and secure their investments, property, and citizens in territory that was not considered safe or that had a radically different-"barbarian" or "uncivilized"-legal regime. ${ }^{66}$ A territorial lease in international law is an agreement-usually a treaty-that creates sovereign-like rights for the lessee state on the territory of the lessor state, through an arrangement that generally emulates a lease in private law. ${ }^{67}$ States, however, are not the same as property owners, and leases between states involve political considerations that differ from the commercial motives of private-law leases. The rights established by a territorial lease comprise a servitude that limits how the lessor state displays its sovereignty in the area involved. A lease is a suspension of sovereignty precisely due to the fact that although sovereignty ultimately (and formally) remains in the hands of the lessor state, the lessee state's rights could correspond to those of a sovereign in substance. International leases are usually used when states have objectives requiring the transfer of some sovereign rights and access to a specific area of another state terri-

64. Territory, Lease, Max Planck Encyclopedia of Pub. Int'l L. (2008).

65. See, e.g., Christopher T. Sandars, America's Overseas Garrisons: The Leasehold Empire (Oxford Univ. Press 2000) (Analyses the political and social problems, which arise when American forces are stationed in other countries); Alexander Cooley, Imperial Wreckage: Property Rights, Sovereignty, and Security in the Post-Soviet Space, 25 InT'L Security, no. 3, 2001, at 100, 127 (Looks at Russia leases of its post-imperial soviet territories and the emergence of hybrid governance structures that challenge classic notion of sovereignty).

66. Martti Koskenniemi, The Gentle Civilizer of Nations: The Rise and Fall of International Law 1870-1960 70-73 (Cambridge Univ. Press 2004); Luigi Nuzzo, Origini di una Scienza: Diritto Internazionale e Colonialismo nel XIX Secolo (2012).

67. Michael J. Strauss, The Leasing of Guantanamo Bay 20-25 (2009). 
tory without transferring the title of sovereignty to the lessee or modifying borders.

Since the late nineteenth century there has been no development of a general international law governing lease-holding. Each bilateral lease is sui generis, and its terms depend upon the particular governing treaty, rather than on generalized well-developed law. ${ }^{68}$ Territorial leases inevitably raise questions of sovereignty. Under international law, such a lease allows a lessor state to grant another subject of international law, usually a state, the right to use and exercise control over part of the former's territory. While formal sovereignty over the land remains with the lessor, it is divorced from jurisdiction which is granted to the lessee. Seeing this ambiguity, international jurists have expressed concern about the leases system of the nineteenth century, arguing that international leases constitute cessions and new forms of colonialism. ${ }^{69}$

China was one of the strongest voices against foreign leases and concessions in the nineteenth and twentieth centuries, and it contributed to developing the doctrine for terminating a territorial lease on grounds of the "inequality of the treaties," lack of reciprocity, and rebus sic stantibus. ${ }^{70}$ Although the lease treaties between the Qing empire and various foreign

68. Territory, Lease, supra note 64 (Ronen offers a definition of territorial leases and provides a review of the various leases from a historical perspective); F. A. VÁli, Servitudes of International Law: A Study of Rights in Foreign Territory 21-56 (2d ed., New York: Frederick A. Praeger 1958) (providing a historical overview of international leases and how their purpose is increasingly economical rather than military).

69. See, e.g., Luis Gerard, Des Cessions Déguisées de Territoires en Droit International Public (1904) (argues that lease territories are disguised territorial cessions); 1 Lassa Oppenheim, International Law: A TreaTISE (2d ed. 1912) (discusses the paradoxes of leases for sovereignty); JEAN Adrien Ferdinand Perrinjaquet, Des Cessions Temporaires de Territoires (1904) (discusses the temporary cession of territories or leases and their legal implications); Albert de Pouvourville, Les Fictions Internationales en Extrême-Orient, Revue Générale de Droit International Public 112-25 (1899) (defines international leases in Asia as a legal fiction); Ellery C. Stowell, International Law: A Restatement of Principles in Conformity with Actual Practice 341 (1931) (he argues that in order to avoid international jealousy international cessions are sometimes disguised as leases).

70. See, e.g., Dong Wang, China's Unequal Treaties: Narrating NaTIONAL History 47-48, 52, 75 (Lexington Books 2008) (describing inequality of treaties, lack of reciprocity, and rebus sic stantibus); CARRAI, supra note 3, at 171-178. 
powers at that time reiterated respect for Chinese sovereignty-for example, the Port Arthur and Talienwan Agreement of 1898 provides that "such lease should not prejudice China's sovereignty over this territory"-Western powers indisputably encroached upon Chinese sovereignty by taking full control and jurisdiction over leased territory that accounted more as a cession of territory. ${ }^{71}$ In his 1912 doctoral dissertation at Columbia University, Wellington Koo, a leading diplomat of Republican China, gave the first account of the foreign rights granted by the unequal treaty system that traditionally starts with the Treaty of Nanjing in $1842 .{ }^{72}$ These rights of aliens "were secured at the outset with the aid of the sword," he wrote, pointing out that "foreigners in China enjoy very many rights and privileges which are not accorded to aliens in other countries," ultimately hampering Chinese sovereignty. ${ }^{73}$ Further, under the international law applicable at that time, the preservation of sovereignty and the alienation of territory through leases were mostly incompatible: while a sovereign enjoyed unfettered dominion within its territory, including the right to lease it to others, such a lease to foreign powers would be inherently detrimental to sovereignty if it was in fact an alienation under the guise of a lease. Although there were different opinions about the relation between sovereignty and international leases at the turn of the century, as Lassa Oppenheim, one of the most influential international lawyers of the early twentieth century, made clear, territory is "the space within which the State exercises its supreme authority." ${ }^{74} \mathrm{Op}$ -

71. See Port Arthur and Talienwan Agreement, China- Russ., 1898, art. 1, Treaties Between the Empire of China and Foreign Powers 278 (1902) ("It being necessary for the due protection of her navy in the waters of North China that Russia should possess a station she can defend, the Emperor of China agrees to lease to Russia Port Arthur and Talienwan, together with the adjacent seas, but on the understanding that such lease shall not prejudice China's sovereignty over this territory."); see also The Kiachow Convention, China-Ger., 1898, art. 3, Treaties Between the Empire of China and ForEIGN Powers 280 (1902) (agreeing that China shall have no voice in the government or administration of the leased territory and that it will be governed and administered during the whole term of ninety-nine years solely by Germany.)

72. V. K. Wellington Koo, The Status of Aliens in China 472 (1st ed., New York: Columbia Univ. 1912).

73. Id. at 350 .

74. Oppenheim, supra note 69, at 231. 
penheim clarified, "two or more full-Sovereign States on one and the same territory are an impossibility." 75 In the specific case of China, Oppenheim insisted that, until the leases expired-in Jiaozhou leased to Germany, Weihaiwei and the New Territories to Britain, and Port Arthur to Russia-"it is the lease-holder who exercises sovereignty over the territory concerned." 76

Qing and Republican China's diplomats and statesmen fiercely opposed both the idea and the reality of effective-suspension of Chinese sovereignty over the leased territories and other foreign concessions. A 1905 statement by diplomat Lü Haihu (吕海寰), ambassador to Berlin from 1898 to 1901, summarized this general view:

[i]f the legislative, judicial and administrative power already belong to the lessee countries (Russia, Germany, Great Britain, France), our country's sovereignty seems to be lost, who am I trying to deceive? Deceive Heaven? Alas! The existence of a country depends on its sovereignty. The existence of sovereignty depends on the nature and the capacities of the sovereign. What matters for the sovereign capacities is being able to exercise the legislative, judicial and administrative power, but today these three powers do not belong to us. What matters for the sovereign nature is the highest principle of non-interference, but today this is restrained and limited by others. Once sovereignty lost its nature and once its capacities have been damaged, then it has been lost. Westerners in one word call it 'extinction of sovereignty' (消滅之主权), or 'alienated sovereignty' (裸主权). Alas! Either extinct or alienated, can it be really called sovereignty? ${ }^{77}$

Could Sri Lankans make similar statements today? It seems that China today, through its "Going Out" strategy and the BRI, is re-proposing the lease of territory in a way that

75. $I d$. at 232 .

76. Id. at 233 .

77. Zhang Yongxin (张用心), Wanqing Zhong Ren de Zhuquan GuannianGuojifa Shijia (晚清中国人的主权观念一国际法视角) [The Chinese idea of sovereignty at the end of the Qing: An international law perspective], 10 BEIJING SHIXUE (北京史学) 102, 123, 128 (2004) (translated by author). 
evokes Western powers' imperialism at the end of the nineteenth century. China's new behavior abroad expressed through the activities of its SOEs and Banks reflects its ongoing global transition: its increased presence and activities abroad resemble those of Western powers in the nineteenth and twentieth centuries, specifically the desire to open markets and opportunities, and to protect investments, people, and property in unsafe territories regulated by different legal, cultural, or political regimes. However, there are also major differences. Importantly, the extent of sovereign control and rights that CMPort exercises over Hambantota seems certainly less than those of Western lessees in previous centuries. Moreover, CMPort, is an SOE, with a different personality from the Chinese state, and thus it does not directly have a sovereign control over Hambantota. The Hambantota Concession Agreement is officially a semiprivate agreement between Sri Lankan government and a Chinese company. The lease in question is located in an area of intersection between public and private law. However, here, the Agreement is considered as falling within the broader category of international leases between China and Sri Lanka states due to the fact that CMPort is a major Chinese SOE, and it acts in name of and in the interests of Chinese central state and the lease of Hambantota in particular was a debt-to-equity deal to repay Sri Lanka Debt to China. While the CMPort activity cannot be immediately assimilated to the Chinese state, it cannot be excluded a priori. As Federica Violi has argued in the event that the States invest their economic reserve for public purposes, "they can be considered legitimate expression of state sovereignty; their actions are based, therefore, on the regulatory requirements and the public policy objectives of the investor State, their use therefore remains strictly linked to the political program of these States."78 While China's changing stance on

78. On the contrary "in the case in which, instead, the economic activity of the State through the work of the SCEs translates into the sole interest of maximizing the investment or profit value of the company itself, without a clear response in terms of the general aims pursued, these can be understood as private investment vehicles, even if they are publicly participated." Federica Violi, L'attribuzione della condotta dei c.d. 'sovereign investors'. Rilievi critici, in LA RESPONSABILITÀ DEGLI STATI E DELLE ORGANIZZAZIONI INTERNAZIONALi: NuOVE FATTISPECIE E PROBLEMI DI ATTRIBUZIONE E DI ACCERTAMENTO 187 (Andrea Spagnolo ed., 2017). 
sovereignty in the few cases it can be observed does not imply that China will necessary become an imperial power mimicking the legal techniques of Western countries, one should be vigilant that the country through its SOEs and Banks does not head in that direction.

Typically, a state-to-state lease will contain three main elements: a transfer of rights from lessor to lessee, a durational aspect, and a compensatory aspect. ${ }^{79}$ The rights that are transferred, the thorniest aspect for sovereignty purposes, can usually be divided into two types: rights associated with the objective of the lease, and jurisdictional rights meant to facilitate the lease's implementation. As for the first type, in the case of the Hambantota Concession Agreement, "SLPA and GOSL will grant (i) to HIPG, the sole exclusive right to develop, operate and manage the Hambantota Port and (ii) to HIPS, the sole and exclusive right to develop, operate and manage the Common User Facilities, for the operation of the Hambantota Port." ${ }^{80}$ Further,

During the first 15 years from the Concession Agreement Effective Date, SLPA and GOSL shall ensure that there shall be no, and shall not obtain any fresh tenders, grant any right to any third party, or discuss, negotiate or enter into any arrangement or agreement with any third party in relation to the development of port/terminal directly in competition with the port services and activities carried out at the Hambantota Port within $100 \mathrm{~km}$ perimeter from the periphery of the Hambantota Port . . . ${ }^{81}$

In this case, the rights tied to the lease's objective include the "exclusive right to develop, operate and manage the Hambantota Port" 82 and more specifically "collecting revenues for all port and marine-related operations covering container, ro-ro [sic], general cargo, bulk cargo, bunkering, LNG, dry dock, warehousing, etc., as well as common user services such

79. Noemi Gal-Or \& Michael J. Strauss, International Leases as a Legal Instrument of Conflict Resolution: The Shab'a Farms as a Prototype for the Resolution of Territorial Conflicts, 11 Touro InT'L L. Rev. 97, 107 (2008).

80. China Merchants Port Holdings Company Limited, supra note 59, at 1.

81. Id. at 3 .

82. Id. at 1,3 . 
as navigation, wharfage, tug, etc." 83 While the port is managed by a "joint company" that collects revenue and manages port operations, as mentioned, CMPort owns $85 \%$ of the port and the Sri Lankan government owns the remaining $15 \%$, allowing CMPort to retain control of board personnel and operating decisions. ${ }^{84}$ As the rights tied to the lease's objectives are narrowly specified in the version made publicly available, it is unclear the extent to which the lessee state has control and jurisdiction of the territory of Hambantota Port.

CMPort has evinced a desire to develop Hambantota even further, but would likely have to pursue these efforts through a formal joint effort with Sri Lanka. CMPort's desire to further develop Hambantota is clear in the Concession Agreement: due to CMPort's "rich experience and resources in implementing the 'Port + Park + City' Model (e.g. Shekou, Zhangzhou). The significant landmass of the project (approximately $11.5 \mathrm{~km}^{2}$ port area) gives leeway for the Group to implement and capitalize on the said model to add substantial value to the port operations and development." 85 CMPort has also entered into a cooperation framework agreement with China Harbour Engineering Company Ltd. (CHEC), an SOE subsidiary of China Communications Construction Company Ltd. (CCCC), to explore future joint development and operation in relation to the Hambantota Port and the adjacent industrial park. ${ }^{86}$ The parties have not yet agreed upon detailed terms and conditions for such cooperation and have yet to sign definitive documentation. ${ }^{87}$

Turning to the second element, the duration of the Hambantota lease is "99 years unless otherwise terminated earlier in accordance with the terms of the Concession Agree-

83. Id. at 8 .

84. Id. at 3 .

85. Id. at 8 .

86. Such cooperation may involve CHEC taking a minority stake in Gainpro Resources Limited (a CMPort subsidiary), and CMPort acquiring a minority stake in the industrial park. $I d$.

87. Dong Zhe (董哲), Hanbantuota Gang: 21 Shiji Haishang Sichou Zhi Lu Xin Mingzhu (汉班托塔港：21世纪海上丝绸之路新明珠 [The Port of Hambantota: The Pearl of the 21st Century Maritime Silk Road], Guoji GuAncha (国际观察) (Oct. 8, 2017), http://www.iis.whu.edu.cn/index.php?id=2133. 
ment," but such terms have not been publicized. ${ }^{88}$ A lease can have a fixed term, an initial term with automatic continuation if neither state takes action to terminate it when the term is reached, or it can last for an indefinite period, with an endpoint based on a geopolitical event, or in perpetuity. When a lease expires, the lessee government usually loses all rights in the leased territory. China choose for the Agreement the duration of 99 years of renewable lease, which are common in international investment contracts on land and natural resources and follow nineteenth-century's common law, where a 99-year lease was the longest possible duration for a lease of real property. ${ }^{89}$ \%, The Concession Agreement also provides, "[a] party may terminate the Concession Agreement if the other parties are in material breach of the Concession Agreement or if certain force majeure events occur."90 Sri Lankan Prime Minister Ranil Wickremesinghe has publicly declared that the Hambantota lease can also be terminated if the need arises. ${ }^{91}$ Despite this declaration, while there have been cases in which lessors have refused to renew undesirable leases, there are no historical examples of a lessor unilaterally denouncing and terminating the lease. ${ }^{92}$ This approach has not been used in part because it risks creating a situation in which the lessee state refuses to leave, and the lessor, especially if it is a relatively weaker state, may not be able to kick the lessee out. This was the case for Guantanamo Bay: Cuba started calling for U.S. departure in 1959 during the Cuban Revolution, but the United States has argued that the 1903 lease is a valid agreement that permits the United States to remain. While the terms of the lease provide that Cuba retains "ultimate sovereignty," the United States enjoys "complete jurisdiction and

88. China Merchants Port Holdings Company Limited, supra note 59, at 1 .

89. See Wang, supra note 70; CARrai, supra note 3.

6 .

90. China Merchants Port Holdings Company Limited, supra note 59, at

91. Interview by Nitin A. Gokhale with Ranil Wickremesinghe, Prime Minister, Sri Lanka, in Hanoi, Vietnam (Sept. 11, 2018), http://www.adader ana.lk/news / 49946/pm-says-that-hambantota-lease-can-be-terminated-ifneed-arises-interview.

92. Michael J. Strauss, Leases and Sovereignty Today, in Territorial Leasing in Diplomacy and International Law 70, 96 (2015). 
control" over the territory. ${ }^{93}$ A similar situation is unfolding between Ukraine and Russia in the Sevastopol port. Russia has leased the port for its Black Sea naval fleet since $2010 .{ }^{94}$ When the lease expired in 2017, Ukraine expressed disinterest in renewing the lease, but the Kremlin evinced strong intent to stay, and Ukraine agreed to extend the lease to 2042. ${ }^{55}$ Despite these examples, James Crawford, a seated judge at the International Court of Justice, suggests the return of leased territories such as Hong Kong, Macau, and the Panama Canal to the grantors may indicate a positive trend toward confirming the lessors' sovereignty. ${ }^{96}$ Without international law rules that systematically governs international leases, a general praxis that confirms one tendency over another is also lacking, leaving the precise terms of each agreement, various anecdotes, and ultimately the political will and power of individual states as determinative.

Turning to the third element, compensation can range from a rent that reflects the territory's actual value to a token rent that simply acts as the lessee state's periodic acknowledgment of the lessor state's sovereignty. According to the released agreements and online media news,

[CMPort] will agree to invest an amount of up to USD1,120.00 million . . . into Hambantota Port and Hambantota port and marine-related activities of which the total amount to be paid to SLPA for the acquisition of the $85 \%$ issued share capital of HIPG shall be USD973.658 million . . . (and HIPG shall use

93. Michael J. Strauss, Guantanamo Bay and the Evolution of International Leases and Servitude, 10 CUNY L. Rev., no. 2, 2007, at 479, 495-496; Alfred de Zayas, The Status of Guantanamo Bay and the Status of the Detainees, 37 U.B.C. L. REv. 277, 290-297 (2004).

94. Ugoda mizh Ukrainoiu ta Rosii'koiu Federatsieiu z pitan' perebuvannia Chornomors'kogo flotu Rosiis'koi Federatsii na teritorii Ukraini [Agreement Between Ukraine and the Russian Federation on the Issues of the Black Sea Fleet], VERHovnA RADA, https://zakon4.rada.gov.ua/laws/show/643_359 (last visited Feb. 8, 2019).

95. Ukraine - Countering Russian Intelligence and Supporting a Democratic State: Hearing on S. 602 Before the Committee on Foreign Relations, 113th Cong. 56 (2014); Kathrin Hille, Ukrainian Port is Key to Russia's Naval Power, Fin. Times (Feb. 27, 2014), https://www.ft.com/content/1f749b24-9f8c-11e3-b6c700144feab7de.

96. James Crawford, Brownlie's Principles of Public International LAw 208 (8th ed. 2012). 


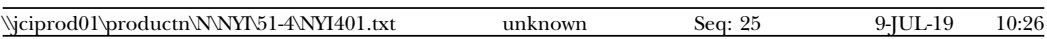

a portion of such amount to acquire $58 \%$ issued share capital of HIPS) and the remaining USD146.342 million . . . shall be deposited into a bank account in the name of [CMPort] in Sri Lanka and utilised for such Hambantota port and marinerelated activities, within one year, as may be agreed with [Sri Lanka's government] and [CMPort] shall be entitled to repatriate any amounts in the bank account at the expiration of the one year period if no agreement has been reached with [Sri Lanka's government] for the use of such funds. ${ }^{97}$

In considering compensation, it is important to remember that both states involved in a lease generally benefit from it: one gets the use of the territory, while the other might receive compensation as a sought-after improvement in political or economic relations. However, in this specific case, the money covers the debt to China and the mismanagement of resources by the Sri Lankan government of which CMPort has taken advantage. So far, all the tranches of the money have been received, although not without issues. CMPort temporarily held back the last tranche of U.S. $\$ 585$ million because it wanted to use the land, specifically the port's man-made island, for entertainment purposes. ${ }^{98}$ The Sri Lankan government opposed CMPort's demand, and after CMPort eventually made the payment, the chairman of the Sri Lanka Ports Authority, Parakrama Dissanayake, remarked that,

Nowhere in the Concessionary Agreement which was signed between the Government and China Merchant Port Holdings on 11 December 2017 does it state that there was a clause for the construction of an entertainment zone which is strictly outside the ambit of CM Port Holdings Ltd . . . . The Agreement is clear that there will be no other activities other than port and marine-related activities within the Hambantota Port and China Merchant Port being

97. China Merchants Port Holdings Company Limited, supra note 59, at $1-2$.

98. Chinese Company Pays Final Tranche of H'tota Port Deal, Daily Mirror (June 20, 2018), http://www.dailymirror.lk/article/Chinese-Company-paysfinal-tranche-of-H-tota-Port-deal-151579.html. 
the second largest port operator in the world, will not digress from its core business . . . ${ }^{99}$

CMPort has abandoned the idea of using the man-made island and other areas for entertainment, and has dropped its request to the Sri Lankan government to use infrastructure within the Hambantota Port for an entertainment zone. ${ }^{100}$ SLPA also insisted that the Hambantota facilities should only be used for marine and port-related activities. ${ }^{101}$ Importantly, the payment failure could have been considered a material breach allowing Sri Lanka to void the lease. However, as the Concession Agreement is not public, the available terms appear opaque, and the difference in the contracting power of China and Sri Lanka is substantial. As such, it is reasonably likely that CMPort will stretch the terms of the lease in order to use the land for other purposes in the future.

\section{Sovereignty and the 99-year Lease Agreement of HAMBANTOTA}

In international leases, there is a presumption that the grantor retains residual sovereignty. ${ }^{102}$ In the Joint Declaration of the PRC and Sri Lanka, the two governments committed to respecting each other's sovereignty and territorial integrity, and, though not published in full, it is possible that the Hambantota Concession Agreement itself mentions "respect for Sri Lanka sovereignty." 103 Even with such language, the agreement could still become a de facto partial cession of territory, ${ }^{104}$ which would ultimately threaten Sri Lanka's sover-

99. Final Tranche For Hambantota Port CM Port To Pay Us $\$ 585$ M This Week, Lanka News Papers (June 20, 2018), https://www.lankanewspapers.com/ 2018/06/20/final-tranche-hambantota-port-cm-port-pay-us-585-m-week/.

100. Id.; China Withholds Hambantota Port Deal's Final Deal's Final Tranche to Sri Lanka, Times OF INDiA (June 11, 2018), http://timesofindia.indiatimes. com/articleshow/64535503.cms?utm_source=contentofinterest\&utm_medi um=text\&utm_campaign=cppst.

101. Lanka News Papers, supra note 99.

102. CrawFord, supra note 96, at 208.

103. Statement from the Chinese Ministry of Foreign Affairs, Zhonghua Renmin Gongheguo He Sililanka Minzhu Shehui Zhu Gongheguo Lianhe Shengming (中华人民共和国和斯里兰卡民主社会主义共和国联合声明) [Joint Statement of the People's Republic of China and the Democratic Socialist Republic of Sri Lanka] (Apr. 9, 2016), https://www.fmprc.gov.cn/web/ziliao_674904/1179_ 674909/t1354364.shtml (translated by author).

104. CRAWFord, supra note 96, at 208. 
eignty in Hambantota. According to international law doctrine, a key element that differentiates leases from disguised cessions is the criterion of the lessor state's consent:

State A may have considerable forces stationed within the boundaries of state B. State A may also have exclusive use of a certain area of state $B$, and exclusive jurisdiction over its own forces. If, however, these rights exist with the consent of the host state then state A has no claim to sovereignty over any part of state B. In such case there has been derogation from the sovereignty of state $\mathrm{B}$, but state A does not gain sovereignty as a consequence. It would be otherwise if state A had been able to claim that exclusive use of an area hitherto part of state B belonged to state A as sovereign, as of right and independently of the consent of any state. ${ }^{105}$

Despite its centrality, consent is sometimes hard to prove. In the lease agreements the Qing government signed with Western powers, for example, the sovereignty of the Qing empire or China was always formally respected in the language of the agreement, and the Qing court effectively consented by signing the relevant treaty. ${ }^{106}$ In reality, however, Western powers failed to respect Qing sovereignty, and the leases effectively became cessions of territory granting sovereignty to the lessee. ${ }^{107}$ Qing and Republican Chinese jurists opposed these leases on the grounds that Western powers imposed them on China through force and a series of unequal treaties. ${ }^{108}$ These leases were eventually abolished as emerging rules in international law stipulated that a lease based on an unequal treaty between a dominant state and a weak state was without legal effect and could be unilaterally terminated. ${ }^{109}$

105. Id. at 204.

106. See, e.g., CARrai, supra note 3 ; WANG, supra note 70 (suggesting that "inequitable treaties might have binding force in legal terms").

107. See, e.g., Carrai, supra note 3; WANG, supra note 70 (suggesting that the treaties were forced, which undermined "the right of a state to protect its people in the enjoyment and maintenance of their material and cultural lives").

108. See, e.g., WANG, supra note 70.

109. Other situations in which a lease can be interrupted include: the rebus sic stantibus according to which the lease can be terminated if there is a fundamental change in the circumstances, the emergence of a peremptory 
In the case of Hambantota, many have lamented that China captured Sri Lanka through a debt trap, which per se does not justify the disposal of Contracts of Treaties in international law. ${ }^{110}$ As Maria Abi-Habib describes, "a way to subjugate a country is through either the sword or debt. China has chosen the latter." 111 Much media and academic attention has focused on this idea, and Hambantota has become the quintessential example of an allegedly predatory behavior bending Sri Lanka's sovereignty to Chinese will. ${ }^{112}$ However, studies show that

[W] hile China was likely in the process of using its economic involvement in Sri Lanka to pursue strategic designs in the Indo-Pacific region, there is little evidence to suggest China pressured Sri Lanka during the Rajapaksa years to reorient its foreign policy or pursue particular domestic objectives; on the contrary, it was the Sri Lankan state under Mahinda Rajapaksa that, in the main, sought to get China to promote its preferences both domestically and internationally. ${ }^{113}$

As discussed above, some reports suggest that Rajapaksa first asked India and the United States to consider financing its vision for Sri Lanka's future by developing the port. ${ }^{114}$ Only after India's refusal did Rajapaksa approach China, which agreed because it made both financial and strategic sense. According to an interview with Rajapaksa, he said:

I asked for it. China didn't propose it. It was not a Chinese proposal. The proposal was from us; they gave money. If India said. Yes, we'll give you a port, I will gladly accept. If America says, We will give a fully

norm of international law that is incompatible with a territorial lease, and the material breach of a lease provisions. See Strauss, supra note 93, at 492; de Zayas, supra note 93, at 301.

110. See, e.g., Abi-Habib, supra note 31 (Argues that China is using a debttrap diplomacy); Chellaney supra note 63; Moramudali, supra note 63.

111. Abi-Habib, supra note 31.

112. See, e.g., Hillman, supra note 63; Harsh V. Pant, supra note 63.

113. DeVotta, supra note 28, at 129-30.

114. Id. at 143-144. 
\begin{tabular}{lllll}
\hline |yciprod01 productn\NWYI51-4WYI401.txt & unknown & Seq: 29 & 9-JUL-19 & 10:26 \\
\hline
\end{tabular}

equipped airport-yes, why not? Unfortunately, they are not offering to us. ${ }^{115}$

Neil DeVotta argues that Rajapaksa's government encouraged Chinese projects to the extent that "there was little reason for China to superimpose its wishes on Sri Lanka."116 More recently, Sri Lanka's Ambassador to China Karunasena Kodituwakku also refuted the theory of a Chinese debt trap:

If anybody is saying that the Chinese government gave its money to put Sri Lanka into a 'debt trap', I don't agree with that. It's an absolutely wrong conclusion. ... The Chinese government [has] never asked to hand over the Port to the Chinese government or to the Chinese venture. It was a proposal that came from Sri Lanka, asking partnership from China . . . . ${ }^{117}$

This is one side of the story; Sri Lanka's oppositional parties and their representatives and journals continue to tell different stories about the terms of the lease and its implications for the country's sovereignty. Without public information, only future document disclosure will give a better picture of whether China intentionally forced Sri Lanka into a debt trap, or whether the Sri Lankan government drove itself into one. What is certain is that Sri Lanka was the weaker party in the negotiations and did not have much leverage against China, the only country willing to invest in Rajapaksa's vision of the future and some of its white-elephant infrastructure projects.

Even in a situation of bargaining equality, the line distinguishing leases from disguised cessions is very fine. ${ }^{118}$ If the lessor-government formally retains de jure sovereign rights over the leased territory, with the exception of those rights granted for the term of the lease, questions arise if the rights granted to the lessee effectively amount to a full control of the territory. In other words, if the rights transferred through a

115. Jyoti Thottam, The Man Who Tamed the Tamil Tigers, Time (July 13, 2009), http://content.time.com/time/world/article/0,8599,1910095,00. html.

116. DeVotta, supra note 28 , at 130 .

117. Hambantota Port is Aot a 'Debt Trap': Lankan Ambassador to China, SunDAY Times (Oct. 6, 2018), http://www.sundaytimes.lk/article/1050362/ hambantota-port-is-not-a-debt-trap-lankan-ambassador-to-china.

118. SANDARs, supra note 65 at 15.; Cooley, supra note 65 at 125-126. 
lease are exceedingly comprehensive, such a lease raises questions about which state has effective control over the territory, and whether the lessor state becomes little more than a passive bystander. This leads directly to theoretical and doctrinal debates about sovereignty. While international law doctrine once considered sovereignty to be absolute and indivisible, more recently definitions see sovereignty as indivisible in substance while acknowledging that the exercise of sovereign rights' can be divided. ${ }^{119}$ It is generally accepted that sovereignty derives from title to territory - the latter being the conceptual legal instrument that legitimizes the relationship between a state and the territory associated with it. ${ }^{120}$ While sovereignty has been seen to withstand a series of limitations without deterioration, effective control over the territory in question has been deemed an essential element for establishing, validating, or confirming title and therefore sovereignty. ${ }^{121}$ Indeed, several international tribunals in the last century established that a

119. Jens Bartelson, A Genealogy of Sovereignty 138, 142, 212 (Cambridge Univ. Press 1995); Eelco. N. van Kleffens, Sovereignty in International Law: Five Lectures, in 82 Recueil Des Cours de L'Academie de Droit InterNATIONAL DE LA HAYE 1, 87 (1953).

120. Ian Brownlie, Principles of Public International Law 119 (2003); Crawford, supra note 96, at 212-234; Malcolm Shaw, Title to Territory In Africa 16 (Oxford Univ. Press 1986); see P. K. Menon, Title to Territory: Traditional Modes of Acquisition by States, 72 Revue de Droit International 1 (1994) (argues that the traditional way of acquiring territory is through title to territory, from which derives sovereignty).

121. Specific limitations that do not degrade sovereignty include: " 1 . Implicit reconfirmation of a state's core sovereign status - states implicitly recognize the underlying sovereign status of other states with which they sign treaties, even when a treaty constrains elements of a state's sovereignty. 2. A limit on one aspect of sovereignty may be offset by a gain in another - states may exercise reciprocal authority on each other's territory or join an international process that creates limits on the sovereignty of all member states while giving each one a role in the mechanism that replaces it. 3. A non-sovereign benefit may enhance a state's sovereignty - when the benefit of accepting a limit on sovereignty is not sovereign in nature (i.e., political, material or financial compensation), it can be seen in sovereign terms if it reinforces a state's ability to effectively control its territory. 4. A state retains its sovereign competence to withdraw from a restrictive arrangement - this competence is displayed by renouncing a treaty or leaving an international organization. 5. A state automatically regains a relinquished element of sovereignty upon termination of the limitthis occurs when a treaty is renounced or expires, when a state leaves an international arrangement that entails limits on its sovereignty, or when such an arrangement is disbanded.” See Strauss, supra note 93, at 486-87. 
state's on-going relationship with its territory, not just its initial relationship, is vital to determining title. ${ }^{122}$ Accordingly, a lease as a de facto transfer of territory contravenes the generally accepted norms of international law for which full control over a state territory is an essential requirement for sovereignty.

The question then becomes what kind of rights are delegated from lessor to lessee over a particular territory, and what kind of control the lessee thereby has over the territory. Sovereignty, as discussed earlier, has to do with territoriality, or with the "attempt by an individual or group ... to influence, affect, or control objects, people, and relationships ... by delimiting and asserting control over a geographic area." 123 Control over territory can vary, and can include (a) the right to exercise jurisdiction; (b) rights to reasonably full control over land and resources within the territory that are not privately owned; (c) rights to tax and regulate uses of that which is privately owned within the state's claimed territory; (d) rights to control or prohibit movement across the borders of the territory; and (e) rights to limit or prohibit "dismemberment" of the state's territories. ${ }^{124}$ One of the thorniest territory and sovereignty-related issues is jurisdiction. Dealing with overlapping claims inspired the practice of extraterritoriality, which refers to "the competence of a State to make, apply and enforce rules of conduct in respect of persons, property or events beyond its territory." 125 In the nineteenth century, imperial powers often coerced weaker states East Asia, including China, to grant extraterritorial rights and thus to exempt their citizens from local law, not only to diplomats, but also to common citizens, traders and missionaries. ${ }^{126}$ According to the traditional view sovereign states enjoy full sovereign powers within their territories, and

122. Island of Palmas (Neth. v. U.S.), 2 R.I.A.A. 829, 839-40 (Perm. Ct. Arb. 1928) (refers to the continuous and peaceful display of the functions of state on a certain territory) ; Minquiers and Ecrehos (Fr. v. U.K.), Judgment, 1953 I.C.J. 47 (Nov. 17). se ti servono altri riferimenti ce ne dovrebbero essere anche di più recenti

123. Robert D. Sack, Human Territoriality: A Theory, 73 Annals Ass' n Am. Geographers 1, 56 (1983).

124. Anna Stilz, Why Do States Have Territorial Rights? 1 Int'l Theory 185, 186 (2009).

125. Extraterritoriality, Max Planck Encyclopedia of Pub. Int'L L. (2012).

126. See, e.g., CARRAI, supra note 3; WANG, supra note 70 (describing extraterritoriality in relation to British and Japanese imperialism). 
any exercise of jurisdiction on another State's territory infringes that State's sovereignty. ${ }^{127}$ Jurisdiction is strictly based on territoriality in the more classical account, and extraterritorial jurisdiction is thus permissible only in exceptional cases.

In all the Chinese territories leased to Western powers in the nineteenth and early twentieth centuries, extraterritoriality was the rule. ${ }^{128}$ Under the lease treaties, nationals of most Western powers residing in leased territories were not subject to Chinese law, but remained under the protection of their own national law, administered in China by their own national officials or in mixed court, as in Shanghai. ${ }^{129}$ China vigorously criticized this system as a derogation of its sovereignty, and it was only in the 1940s, after decades of lobbying in major international law forums, that Chinese jurists and diplomats were able to abrogate the unequal treaties and extraterritoriality provisions deemed to be limiting "China's political, jurisdictional and administrative freedom of action." 130

With the current globalization of trade and finance, territory seems to have lost part of its resonance as a basis for jurisdiction, especially in international criminal, economic, human rights, and environmental law. The lawfulness of extraterritoriality is still governed by the 1926 Lotus case, which set forth three main principles: first, whether a state may lawfully exercise extraterritorial jurisdiction is a matter of international law; second, that international law prohibits the exercise of extraterritorial enforcement jurisdiction unless this is explicitly permitted; and third, that the exercise of extraterritorial prescriptive and adjudicative jurisdictions are permitted only if there is a sufficient connection between the state exercising it and the extraterritorial event. ${ }^{131}$

127. Extraterritoriality, supra note 125 .

128. Pär Kristoffer Cassel, Grounds of Judgment: Extraterritoriality and Imperial Power in Nineteenth-Century China and Japan 10 (Oxford Univ. Press, 2012); Teemu Ruskola, Legal Orientalism: China, The United States, and Modern Law 118 (Harvard Univ. Press 2013).

129. Robert T. Bryant, Jr., Extraterritoriality and the Mixed Court in China, 13 VA. L. REV., no. 1, 1926, at 27.

130. Quincy Wright, The Washington Conference, 16 Am. Pol. Sci. Rev., no. 2, 1922, at 2285.

131. Extraterritoriality, supra note 125; Lotus (Fr. v. Turk.), 1927 P.C.I.J. (ser. A) No. 10 (Sept. 7). 
With Hambantota, while the publicly-disclosed terms of the Concession Agreement provide that CMPort will have the "exclusive right to develop, operate and manage" the leased area, it remains unclear the extent to which Sri Lanka gave up its jurisdiction and control over the territory to CMPort and indirectly to Chinese state, and the future of the port. ${ }^{132}$ Moreover, as it has been discussed earlier there is a fine line that divides Ari Lanka exercise of sovereignty and derogation of sovereignty, which greatly depend on the capacity of Sri Lanka to regain full control over the territory it leased. Giving its strategic importance, the port has the potential to become a new Dubai or Singapore. However, the likelihood of potential conflicts in authority and jurisdiction between the two controlling firms at Hambantota is high. Per existing port management norms, the company that controls operations makes decisions on substantive issues, such as how ships must enter and leave harbor, port security services, bunkering, inner anchorage services, and ship repairing. At Hambantota, the HIPS' right to control warship movements may result in a clash of authority with CMPort. The Chinese are likely to have anticipated these problems, inserting clarifying clauses in the Concession Agreement that recognize CMPort's final authority in cases of disagreement with HIPS, which is nevertheless still under Chinese control. However, issues of jurisdiction remain regarding Chinese nationals and people living and working in the leased territory. It is also unclear whether Sri Lankan and Chinese sovereign immunity will be respected or waived. Recently, excerpts from a 2014 contract between the Chinese Export-Import Bank of China and the Republic of Kenya for the loans used to build Kenya's Standard Gauge Rail, raised much concern about the possible Chinese encroachment upon Kenya's sovereignty. ${ }^{133}$ The excerpts specified not only that all contract disputes must be arbitrated in China, but also that " $[\mathrm{n}]$ either the borrower (Kenya) nor any of its assets is entitled to any right of

132. Press Release, China Merchants Port Holdings Company Limited, Potential Disclosable Transaction Concession Agreement in Relation to Hambantota Port, Sri Lanka (Jul. 25, 2017), http://www.cmport.com.hk/ UpFiles/bpic/2017-07/20170725061311456.pdf.

133. Edwin Okoth, SGR Pact with China a Risk to Kenyan Sovereignty, Assets, The Nation (Jan. 19, 2019), https://www.nation.co.ke/news/Hidden-trapsin-SGR-deal-with-China/1056-4932764-ebw46r/index.html. 
immunity on the grounds of sovereignty."134 If the Hambantota Port Lease Agreement contains similar provisions, Sri Lankan sovereignty would be partly compromised. Questions also remain about human rights obligations toward the Sri Lankan population and Chinese nationals associated with the territory in terms of whether Chinese or Sri Lankan law will be followed. It is also unclear which court will have jurisdiction over the people of Hambantota-whether the Chinese or Sri Lankans will legislate, and through which country's organs of authority. Especially now, with great instability in the country, Rajapaksa's coup d'état in November 2018, and the many violent local protests against Chinese presence and investments, these unanswered questions of jurisdiction remain crucial for the smooth development, operation, and management of Hambantota.

Another sovereignty-related question is the use CMPort can make of the leased land, and whether it has the rights to tax and regulate privately owned property, and to exercise control over the land and resources in Hambantota that are not privately owned. As for the former, in 2017 the Sri Lankan Parliament passed tax exemptions for the Chinese investors at Hambantota through an income tax holiday of up to 32 years. ${ }^{135}$ This shows that the Sri Lankan government retains control over taxation, suggesting CMPort lacks complete control over the use of the territory. As discussed, a Chinese proposal for entertainment usage has already been opposed by the Sri Lankan government, which insisted that China is only allowed to conduct activities for commercial purposes. ${ }^{136}$ Given Sri Lanka's strategic importance, one of the main concerns about the 99-year lease is that it might be converted into a military base, in accordance with the "string of pearls" the-

134. Id

135. Shihar Aneez \& Ranga Sirilal, Sri Lanka Parliament Backs Tax Exemptions for Port Deal with Chinese, Reuters, Dec. 8, 2017, https://www. reuters.com/article/us-sri-lanka-china-port/sri-lanka-parliament-backs-taxexemptions-for-port-deal-with-chinese-idUSKBN1E22FA.

136. Chris Kamalendran, Lanka Disallows Entertainment Island Near Hambantota Port, Sunday Times (June 24, 2018), http://www.sundaytimes.lk/ 180624/news/lanka-disallows-entertainment-island-near-hambantota-port299621.html. 
ory. ${ }^{137}$ The concern is not unfounded, especially considering the docking of a submarine in Colombo Harbour in 2014 could be seen as China expressing an interest in using Sri Lanka for a naval expansion into the Indo-Pacific region. ${ }^{138}$ The People's Liberation Army Navy submarine should have berthed under the control of SLPA at an SLPA berth, in accordance with Sri Lankan regulation stipulating that foreign vessels, including military ones, be accommodated at state-owned facilities. Instead, the submarine came alongside the deepwater Colombo South Container Terminal, a facility built, controlled, and run by Chinese's CMPort, which now also controls Hambantota Port. ${ }^{139}$ The security establishments of India and the United States cannot ignore Sri Lanka's critical position in South Asia located at the center of essential sea lanes. Without other military replenishment sites along the principal sea lanes in the Eastern Indian Ocean, Sri Lanka has the potential to serve as a prime logistics hub for Chinese war and merchandise vessels. ${ }^{140}$

Despite these justified concerns, Sri Lanka's government has made reassurances that the final lease agreement forbids military activity without its invitation, and that the Hambantota Port is under Sri Lankan sovereignty. The security concerns over a port commercially run by a Chinese company were dismissed by the Sri Lankan government, which recently moved its southern naval command to the facility. The Sri Lankan Prime Minister's Office announced in June that " $[\mathrm{t}]$ here is no

137. See Penrson, supra note 24; Jamie Tarabay, With Sri Lankan Port Acquisition, China Adds Another 'Pearl' to its 'String,' CNN (Feb. 4, 2018), https:// www.cnn.com/2018/02/03/asia/china-sri-lanka-string-of-pearls-intl/index.html (discusses the strategic importance of Hambantota).

138. Shihar Aneez, Chinese Submarine Docks in Sri Lanka Despite Indian Concerns, Reuters, Nov. 2, 2014, https://www.reuters.com/article/sri-lankachina-submarine/chinese-submarine-docks-in-sri-lanka-despite-indian-con cerns-idINKBNOIM0LU20141102.

139. See Sri Lanka Ports Authority Act, No. 51 of 1979, Sri Lanka Port Authority Regulation (1979), vol. 7 (discusses Sri Lanka Port Authority regulations for submarine berth); Abhijit Singh, Sri Lanka's Hambantota Gambit, LiveMint (Aug. 16, 2017), https://www.livemint.com/Opinion/qKTtTf3S4 UwaFrSnD3KDJJ/Sri-Lankas-Hambantota-gambit.html (reported the submarine coming alongside Colombo South Container Terminal).

140. Bernard D. Cole, What Do China's Surface Fleet Developments Suggest about Its Maritime Strategy?, in China's Evolving Surface Fleet, 17, 22-24 (Peter A. Dutton \& Ryan D. Martinson eds., Naval War College Press 2017). 
need to be frightened as security of the [Hambantota Port] will be under the control of Sri Lanka Navy. . .."141 He "clarified that Sri Lanka and its people own control over the port, and refute[d] allegations that a 'Chinese colony is being built' there," 142 adding that the government has told Beijing that China could use the facility only for commercial activities and not towards military ends. ${ }^{143}$ In October 2018, Prime Minister Ranil Wickremesinghe, speaking at a gathering at the Oxford Union, also rejected U.S. claims that China would set up a "forward military base" at the port. ${ }^{144} \mathrm{He}$ said that some people are seeing "imaginary Chinese Naval bases in Sri Lanka. Whereas the Hambantota Port is a commercial joint venture between our Ports Authority and China Merchants-a company listed in the Hong Kong Stock Exchange." 145 Also in October, Kodituwakku pointed out in response to media concerns that China was "militarizing" the port that "in Sri Lanka's case, from the very beginning, we have very clearly indicated to the Chinese side, it's only an economic venture," reiterating that Sri Lanka does not allow anybody to interfere with its defence affairs. ${ }^{146}$ Indeed, he said, Sri Lanka decided to shift a naval base to Hambantota to confirm this. "The security of Port Hambantota, the security of territorial coverage of Sri Lanka in the Indian Ocean, is an entire matter for Sri Lankan security forces," Kodituwakku insisted. "China never

141. Sri Lanka's to Move Naval Unit to China-run Hambantota Port, LiveMinT (June 30, 2018), https://www.livemint.com/Politics/34gwxEv8f6mWxTSs 8MaGsK/Sri-Lanka-to-move-naval-unit-to-Chinarun-Hambantota-port.html.

142. Shen Shiwei, Underwater Myth of Sri Lanka's Hambantota Port Deal, Daily Fin. Times (Aug. 10, 2018), http://www.ft.lk/opinion/Underwatermyth-of-Sri-Lanka-s-Hambantota-Port-deal/14-660586.

143. Sri Lanka to Base Nayy's Southern Command at Chinese-run Hambantota Port, South China Morning Post, (June 30, 2018), https://www.scmp.com/ news/china/diplomacy-defence/article/2153246/sri-lanka-base-navys-southern-command-chinese-run; Sri Lanka to Move Naval Unit to Hambantota, THE Hindu (June 30, 2018), https://www.thehindu.com/news/international/srilanka-to-move-naval-unit-to-hambantota/article24300898.ece.

144. PM Rejects Claims of Chinese Military Base at Hambantota During Oxford Union Address, Sunday Times (Oct. 11, 2018), http://www.sundaytimes.lk/ article/1050749/pm-rejects-claims-of-chinese-military-base-at-hambantotaduring-oxford-union-address-read-full-text.

145. Id.

146. Hambantota Port is not a 'Debt Trap': Lankan Ambassador to China, SunDAY Times (Oct. 6, 2018), http://www.sundaytimes.lk/article/1050362/ hambantota-port-is-not-a-debt-trap-lankan-ambassador-to-china. 
asks us. We never offered it." 147 As per the latest draft of the agreement, revised on March 25, 2017, the overall security of Hambantota Port will be controlled by an Oversight Committee comprised of representatives of the Sri Lankan Navy, Sri Lankan Police, SLPA, and the Secretary to the Ministry of Strategic Development and International Trade. ${ }^{148}$ However, internal security for the port will be controlled only by the Chinese company, thus providing a loophole through which the Chinese could employ military personnel for security reasons. ${ }^{149}$ The Sri Lankan government has indicated that such an arrangement would require substantive changes in the law with regard to the port, but would neither affect the sovereignty of the country nor lead to any inimical military presence. ${ }^{150}$ In any event, as restrictive factors increasingly limit the sovereign rights of the lessee state, the CMPort is increasingly involved and actively displaying sovereign powers within the territory.

\section{Conclusion}

China is expanding its interests abroad. While in its official language and rhetoric China continues to support in its foreign policy non-intervention and sovereignty, the protection of Chinese interests, investments and people outside of its sovereign borders have become increasingly important as part of the "Going Out" strategy and the BRI and the reality might not match such rhetoric. In other words, China might start to interfere more in the domestic affairs of the countries in which it invests. While the transformation from being inwardlooking to being more aggressively outward-looking does not necessarily mean China will become an imperial power and use the same legal techniques Western powers have used, the 99-year lease of Hambantota Port certainly seems to be a step in that direction-a step that may leave Sri Lanka's government and people with only residual sovereignty in that territory. China seems to follow Western countries' past lease prac-

147. Id.

148. Patrick, supra note 40 at 4.

149. Id.

150. Gurpreet S. Khurana, Common Public Good at Sea: Evolving Architecture In The Indo-Pacific Region, Nat'L Mar. Found. Int'l Fleet Rev. (Jan. 4, 2016); Patrick, supra note 40 at 4. 
tices, and its financing the debt of another country does not deviate from long-adopted practices. Because each international lease is unique and should be examined as such, China's lease of Hambantota should be examined in its own investigated terms, when and if it is made available to the public. While the true nature of Sri Lanka's pact with China will only be revealed through a close reading of the document itself, the Concession Agreement has the potential to limit and challenge Sri Lankan sovereignty. However, China does not seem to have full control over the territory so far, as it cannot use the land for purposes other than commercial ones and the Sri Lankan government still holds many of the sovereign rights. Sri Lanka's sovereignty in Hambantota does not seem to be substantially void, and it certainly still constitutes a legal fact, but the Sri Lankan government must continue to be clear about the specific use and control of the territory allowed to the Chinese SOE.

Ultimately, the 99-year lease of Hambantota Port exposes some of international law's conceptual and legal gaps. In particular, it exposes the contested and political nature of sovereignty. International leases are allowed under international law, but they constitute a grey area in which the meaning of sovereignty is blurred and in which fundamental sovereign rights of the state are exceptionally suspended. International leases, and the extraterritoriality associated with them, can undermine not only countries' sovereignty, but the very international system itself, as they limit the exercise of sovereignty that together with sovereign title constitute the pillars of international law and society. Even if Sri Lanka preserves its de jure sovereignty in the Concession Agreement for Hambantota, the fundamental question remains as to where ultimate sovereignty resides and whether Sri Lanka will become dependent on China to act as sovereign in its territory. No one knows what Hambantota Port will look in 99 years' time. Neither international law nor Chinese policy can confirm whether Sri Lankan sovereignty will be restored to de facto sovereignty, whether China will annex the territory, or if Sri Lanka will sell Hambantota to China. Annexations are legal phenomena, but they result from political decisions on lessees' part toward the leased territory, which in the course of 99 years might have 
accumulated further geopolitical significance. ${ }^{151}$ Oppenheim's remark at the beginning of the last century that "two or more full-Sovereign States on one and the same territory are an impossibility" continues to haunt international law, and will ultimately lead to an even more fundamental debate about sovereignty's political and contested nature. ${ }^{152}$ The lease of the Hambantota Port is a vivid example of this ongoing debate and must be carefully analyzed as such.

151. Annexation, Max Planck Encyclopedia of Pub. Int'l L. (2006).

152. Oppenheim, supra note 69, at 231. 
